\title{
Response of Potato (Solanum tuberosum L.) to Increasing Growing Season Temperature Under Different Soil Management and Crop Protection Regimes in the Upcountry of Sri Lanka
}

\author{
K.M.R.D. Abhayapala*, W.A.J.M. De Costa ${ }^{1}$, R.M. Fonseka ${ }^{1}$, K. Prasannath ${ }^{2}$ \\ D.M. De Costa ${ }^{3}$, L.D.B. Suriyagoda ${ }^{1}$, P.D. Abeythilakeratne ${ }^{4}$ and M.M. Nugaliyadde ${ }^{5}$
}

\author{
Postgraduate Institute of Agriculture \\ University of Peradeniya \\ Sri Lanka
}

\begin{abstract}
The national average potato yield of Sri Lanka is lower than its global average with the absence of an optimum temperature regime for tuber bulking being a major contributory factor. Increasing air temperatures due to the enhanced greenhouse effect have the potential to further reduce potato yields in Sri Lanka. Therefore, the primary objective of this study was to determine the response of phenology, growth and yield of potato to increasing temperature in the upcountry of Sri Lanka, which is the principal potato-growing region of the country. Furthermore, effectiveness of an integrated pest management (IPM) package and a modified soil management regime aimed at soil moisture conservation and reducing excessive use of synthetic pesticides and fertilizers were also tested. A field experiment was conducted during Maha 2012/2013 at Sita-Eliya (SE) and Rahangala (RG) of Sri Lanka, which represented a temperature increase of $5.2{ }^{\circ} \mathrm{C}$ from $15.1{ }^{\circ} \mathrm{C}$ to $20.3{ }^{\circ} \mathrm{C}$. Potato (Solanum tuberosum L.) variety Arnova was grown with four treatments: $T_{1}-$ Recommended crop management; $T_{2}$ - Mulching with recommended crop protection (nonIPM) and fertilization (100\% inorganic fertilizer); $T_{3}-$ Mulching with IPM and recommended fertilization and $T_{4}-$ Mulching with IPM plus $25 \%$ of $N$ provided as organic amendments. Crops matured a month earlier at the higher temperature site RG, i.e. in 81 days as compared to 111 days at SE. However, the thermal duration from planting to maturity was approximately similar at both sites (i.e. $1689{ }^{\circ} \mathrm{Cd}$ and $1662{ }^{\circ} \mathrm{Cd}$ at $S E$ and $R G$, respectively). Crop growth rates were higher at $R G$, thus compensating for the lower crop duration so that total dry weights at harvest and tuber yields of $T_{1}$ did not differ significantly between the two sites. At both sites, the tuber yield of $T_{2}$ did not differ significantly from $T_{1}$.

The growth and yield response to mulching was greater at $R G$ due to the lower rainfall and low soil fertility as compared to SE. The IPM treatments (i.e. $T_{3}$ and $T_{4}$ ) resulted in an effective control of the incidence and severity of late blight at $S E$ but not at $R G$, where the prevailing temperature regime was optimum for spore formation of the late blight pathogen. Consequently, while the tuber yields did not show significant inter-treatment variation at SE, at $R G$ the IPM treatments (i.e. $T_{3}$ and $T_{4}$ ) showed significantly lower yields than the non-IPM $\left(T_{1}\right.$ and $\left.T_{2}\right)$ treatments. Analysis of the inter-relationships between tuber yield, yield components and growth data showed that potato yields of the present study were primarily source-limited.
\end{abstract}

Keywords: Crop protection, increased temperature, potato, soil management

\footnotetext{
Department of Crop Science, Faculty of Agriculture, University of Peradeniya, Sri Lanka

Faculty of Agriculture, Eastern University, Batticaloa, Sri Lanka

Department of Agricultural Biology, Faculty of Agriculture, University of Peradeniya, Sri Lanka

Regional Agricultural Institute, Rahangala, Sri Lanka

Agricultural Research Station, Sita-Eliya, Sri Lanka

Corresponding author: ruvini.dilrukshi@yahoo.com
} 


\section{INTRODUCTION}

Potato (Solanum tuberosum L.) ranks fourth among the world's food crops and is the staple food of almost half of the world's population (Khan \& Khan, 2010). In Sri Lanka, total national potato production in 2009/2010 was 51,294 tonnes and the extent under cultivation was 3,748 ha (Anonymous, 2010). At present, potato is extensively cultivated in highlands in the districts of Nuwara-Eliya in the up-country wet zone (WU3) and Badulla in the upcountry intermediate zone (IU3d). At present, the local production of potato is not sufficient to meet Sri Lanka's potato demand and thus necessitates importation. Therefore, Sri Lanka has to import 3,000-3,500 tons of seed potato every year at a cost of Rs. 1.7 billion (Nugaliyadda, 2011). Hence, there is a need to increase local potato production to reduce the outflow of foreign exchange.

Absence of specific climatic conditions for tuber bulking in potato is a major constraint to expand its cultivated extent in Sri Lanka. Even in the areas where potato is currently cultivated, the climatic conditions are not optimum for achieving the yield potential. Accordingly, the average productivity of potato in Sri Lanka is $13.47 \mathrm{t} \mathrm{ha}^{-1}$ which is much lower than the global average of $17.18 \mathrm{t} \mathrm{ha}^{-1}$ (Pandey, 2008). Long-term increases in air temperatures of all agro-climatic regions of Sri Lanka, along with greenhouse effect-induced global warming (IPCC, $2001 \&$ 2007), are likely to impose further environmental constraints to increasing potato yields in Sri Lanka. A strong negative impact of climate change on potato yields in the low latitudes (i.e. the tropics) has been predicted (Hijmans, 2003). Therefore, one objective of the present study was to quantify the response of potato yields in Sri Lanka to environmental variation as represented by two experimental sites, namely, Nuwara-Eliya in the up-country wet zone and Rahangala in the up-country intermediate zone.

Apart from the environmental constraints, at present, potato cultivation in Sri Lanka has several critical issues, which have to be addressed urgently to ensure its long-term sustainability. Extremely high use of pesticides and inorganic fertilizers on intensive cultivations of potato on steep slopes of the up-country is one such issue (Watawala et al., 2009; Wijewardana, 1996; Wijewardana, 2001; Suriyagoda et al., 2012). Because of the high precipitation levels in the up-country, a high proportion of the applied inorganic fertilizer and pesticides are leached to ground water causing serious environmental and health hazards (Wijewardena, 1996; Robertson \& Vitousek, 2009; Watawala et al., 2009). Hence, there is a need to explore the possibility of cultivating potato with reduced use of pesticides and inorganic fertilizer. Accordingly, another objective of the present work was to determine the effectiveness of an integrated pest management (IPM) package with reduced pesticide application and a modified nutrient management regime in which a part of the nitrogen requirement is supplied by organic manure.

The specific objectives of the study were to determine the response of phenology, vegetative growth and tuber yield of potato (var. Arnova) to: (a) the environmental variation represented by the up-country wet zone and the up-country intermediate zone of Sri Lanka; (b) modified crop protection practices to include IPM aiming minimal use of pesticides and (c) modified nutrient management to include organic amendments and reduce the use of inorganic fertilizer. Further objectives were to quantify the disease incidence and assess the effectiveness of the tested IPM package for potato. 


\section{METHODOLOGY}

A field experiment was conducted at the Agricultural Research Station, Sita-Eliya to represent the up-country wet zone and the Agricultural Research Station, Rahangala to represent the up-country intermediate zone. The environmental conditions of the two sites are shown in Table 1.

Table 1. Site characters in Sita-Eliya and Rahangala

\begin{tabular}{|c|c|c|c|c|}
\hline Location & $\begin{array}{l}\text { Agro-ecological } \\
\text { region }^{1}\end{array}$ & Soil type $^{2}$ & $\begin{array}{l}\text { Mean annual } \\
\text { rainfall }(\mathbf{m m})^{2}\end{array}$ & $\begin{array}{c}\text { Mean annual } \\
\text { temperature }\left({ }^{0} \mathrm{C}\right)^{3}\end{array}$ \\
\hline Sita-Eliya & WU3 & $\begin{array}{l}\text { Red Yellow } \\
\text { Podsolic }\end{array}$ & 2000 & 16.2 \\
\hline Rahangala & IU3d & $\begin{array}{l}\text { Red Yellow } \\
\text { Podsolic }\end{array}$ & 1450 & 19.6 \\
\hline
\end{tabular}

Source: ${ }^{1}$ Punyawardana (2008); ${ }^{2}$ Mapa et al. $(1999 ; 2005) ;{ }^{3}$ Natural Resource Management Centre, Department of Agriculture, Sri Lanka. Annual mean temperature was calculated using 10-year monthly average maximum and minimum temperatures (Sita-Eliya from 2000 to 2009; Rahangala from 1992 to 2001).

The experiment was laid out as a Randomized Complete Block Design (RCBD) with four treatments in three replicates. The high yielding and heat tolerant potato variety Arnova was used. Plot size was $25 \mathrm{~m}^{2}(5 \mathrm{~m} \times 5 \mathrm{~m})$ and contained 144 plants at inter- and intra-row spacings of $60 \mathrm{~cm}$ and $25 \mathrm{~cm}$, respectively. Plots were separated by a distance of $1 \mathrm{~m}$ from each other. Details of the four treatments are given below.

Treatment $1\left(T_{1}\right)$ included the current recommended management practices in terms of fertilization and crop protection by the Department of Agriculture (Anonymous, 1990). Treatment $2\left(\mathrm{~T}_{2}\right)$ included mulching with current recommended fertilization and crop protection practices. Treatment $3\left(\mathrm{~T}_{3}\right)$ included mulching with modified crop protection to include an integrated pest management (IPM) package with recommended fertilizer management practices. Treatment $4\left(\mathrm{~T}_{4}\right)$ included mulching, modified crop protection (i.e. IPM) with modified nutrient management. For mulching site specific materials were used at the rate of $8 \mathrm{t} \mathrm{ha}^{-1}$. Tithonia diversifolia and Panicum spp. were used at Sita-Eliya and Rahangala, respectively. The IPM package was designed after preliminary laboratory testing and included following treatment combinations: (a) A soil application of a $2 \%$ bleach solution after crop establishment for eliminating the harmful effects of soil borne pathogens; (b) A weekly foliar application of baking soda $\left(\mathrm{NaHCO}_{3}\right)$ solution for controlling the late blight disease; (c) A monthly application of a talc based biopesticide (Bacillus megaterium) to the foliage for reducing the fungal pathogens; (d) A one-time application of neem seed kernel extract solution for the control of insect pests and (e) Establishment of two border rows of maize around each plot for reducing the abundance of insect pests. The plots containing the IPM treatments (i.e. $\mathrm{T}_{3}$ and $\mathrm{T}_{4}$ ) were separated from plots which were managed with conventional crop protection practices $\left(\mathrm{T}_{1}\right.$ and $\left.\mathrm{T}_{2}\right)$ by a thick barrier of maize rows to prevent the pesticide drift. Modified nutrient management included the addition of $25 \%$ of the crop's nitrogen requirement through organic manure while providing $75 \%$ of the nitrogen requirement through inorganic fertilizer. During the periods of heavy rainfall, mancozeb (80\% W.P.) and mancozeb with metalaxyl (80\% W.P.) were applied to $\mathrm{T}_{1}$ and $\mathrm{T}_{2}$ treatments at 4-day intervals. When late blight disease incidence was severe, above mentioned agrochemicals were applied weekly to $\mathrm{T}_{3}$ and $\mathrm{T}_{4}$ treatments as well. 
Daily meteorological data (i.e. rainfall, sunshine duration, maximum and minimum air temperatures, relative humidity and average wind speed) were recorded in meteorological stations located at the experimental sites for the duration of the experiment. Soil chemical properties were determined for soil samples obtained at 0-30 cm depth before crop establishment. Soil $\mathrm{pH}$ and EC were tested by the simple immersing electrode method. Total soil nitrogen, organic carbon, exchangeable potassium and available phosphorus were respectively measured using the Modified Kjeldahl method, the Walkley and Black method, the flame photometer method and the Olsen's method (Van Ranst et al., 1999). The number of days to harvest was recorded. Crop biomass and its partitioning to leaves, stems, roots and tubers were measured by destructive sampling at $50 \%$ canopy closure using one plant per plot. Leaf area was measured using an automatic leaf area meter (AAM9, Hayashi Denko Co. Ltd, Tokyo) and dry weights were obtained by oven-drying at $60{ }^{\circ} \mathrm{C}$ to a constant weight. The tubers were harvested at $80 \%$ leaf senescence. A sample of 10 plants per plot was used to measure the number of tubers per plant and tuber fresh weight.

Incidence and severity of late blight and incidence of bacterial wilt were quantified at different stages of the crop growth, namely, the initial (14 and 21 days after planting), crop development ( 28 and 35 days after planting), mid-season (42 and 56 days after planting) and late season (63 and 70 days after planting) stages. The initial stage corresponded to the stolon development stage while the crop development stage corresponded to the tuberization stage while mid- and late season stages corresponded to tuber bulking and maturity stages, respectively. Incidences of late blight and bacterial wilt were quantified as the percentage of affected plants in a given plot with respect to the total number of plants in the same plot. Severity of late blight was calculated as the percentage of leaves showing symptoms in 10 randomly selected plants from each plot.

Cumulative thermal duration from planting to harvesting was calculated by cumulating the daily mean temperatures of each site separately, assuming a base temperature of $0{ }^{\circ} \mathrm{C}$. Crop growth rate (CGR) s from planting to $50 \%$ canopy closure and harvesting were calculated as the increase in total crop dry weight per $\mathrm{m}^{2}$ per day over the respective periods. Count data were analyzed using PROC CATMOD and PROC PROBIT procedures and parametric data were analyzed using analysis of variance in the General Linear Model (PROC GLM) in SAS. Statistical significance was tested at $\alpha=0.05$.

\section{RESULTS}

\section{Meteorological and soil conditions at the two experimental sites}

There were clear differences between the two sites in terms of meteorological conditions. At Sita-Eliya daily mean temperature ranged between $12-18{ }^{\circ} \mathrm{C}$ whereas the corresponding range at Rahagala was $16-25{ }^{\circ} \mathrm{C}$ (Fig. 1). Accordingly, the seasonal mean temperature was higher at Rahangala with $20.3 \pm 1.4^{\circ} \mathrm{C}$ as compared to Sita-Eliya $\left(15.1 \pm 1.4^{\circ} \mathrm{C}\right)$. The respective total rainfall during the season at Sita-Eliya and Rahangala were 914.1 and $411.9 \mathrm{~mm}$ with 56 and 37 rain days, respectively. The major individual rainfall events were heavier at SitaEliya, with the highest being $127 \mathrm{~mm}_{\text {day }}{ }^{-1}$ in comparison to the highest of $65 \mathrm{~mm}$ day $^{-1}$ at Rahangala. Soil characteristics of the two sites were also differed appreciably with the SitaEliya soil having a lower $\mathrm{pH}$ but a higher EC and greater nutrient and organic matter contents than at Rahangala (Table 2). 


\section{Crop phenology}

The duration from planting to final harvest (at $80 \%$ leaf senescence) was similar among treatments in a given site while it differed significantly $(\mathrm{p}<0.05)$ between the two sites with 111 and 82 days for Sita-Eliya and Rahangala, respectively. Earlier maturity of potato at Rahangala was primarily due to its higher temperature, which has been found to be a major factor regulating crop phenology, biomass accumulation and tuber development in potato (Bodlaender, 1963; Gregory, 1965; Wheeler et al., 1986; Woff et al., 1990). Interestingly, despite the substantial difference in the total crop duration between the two sites, the cumulative thermal time from planting to maturity was approximately similar with $1689{ }^{\circ} \mathrm{Cd}$ and $1662{ }^{\circ} \mathrm{Cd}$ at Sita-Eliya and Rahangala respectively. This showed that temperature was the primary factor that was controlling the duration of potato crop between the two sites.

\section{Growth parameters}

There was a highly significant $(\mathrm{p}=0.001)$ treatment (site) effect on LAI at $50 \%$ canopy closure. When the variation of LAI at the two sites were analyzed separately, both sites showed significant $(\mathrm{p}<0.05)$ inter-treatment variation (Fig. 2). At Rahangala, $\mathrm{T}_{1}$ and $\mathrm{T}_{2}$ showed significantly greater LAI than $\mathrm{T}_{3}$ and $\mathrm{T}_{4}$. On the other hand, at Sita-Eliya, $\mathrm{T}_{1}$ and $\mathrm{T}_{4}$ had significantly greater LAI than $\mathrm{T}_{2}$ and $\mathrm{T}_{3} . \mathrm{T}_{1}$, which was the control treatment managed with the current recommended crop management, showed similar LAIs at 50\% canopy closure at both sites. However, there was significant $(\mathrm{p}<0.05)$ difference between-site variation for LAI of $T_{2}, T_{3}$ and $T_{4}$. In $T_{2}$, Rahangala had a greater LAI whereas in $T_{3}$ and $T_{4}$, Sita- Eliya had greater LAI. Severe incidence of late blight (reported elsewhere in this paper), which had managed with IPM, was a major contributory factor for the substantially low LAI resulted in $\mathrm{T}_{3}$ and $\mathrm{T}_{4}$ at Rahangala.

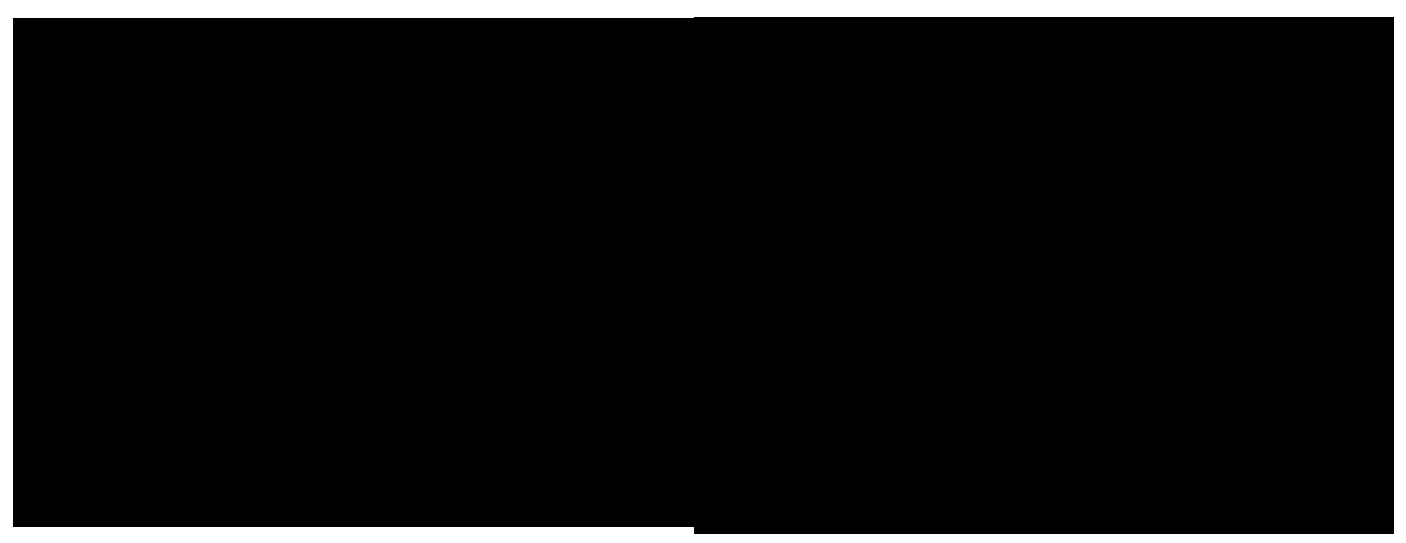

Fig. 1. Seasonal variation of daily mean temperature (curve) and daily rainfall (bars) at Rahangala (top) and Sita-Eliya (bottom) 
Table 2. Initial soil characteristics of the two experimental sites

\begin{tabular}{|c|c|c|c|c|c|c|}
\hline Site & pH & $\begin{array}{c}\mathrm{EC} \\
\left(\mu \mathrm{S} \mathrm{m}^{-1}\right)\end{array}$ & $\begin{array}{l}\text { Total N } \\
\left(\mathrm{mg} \mathrm{N} \mathrm{g}^{-1}\right. \\
\text { soil) }\end{array}$ & $\begin{array}{c}\text { Exchangeable } \\
\mathrm{K}^{+}\left(\mathrm{mg} \mathrm{K} \mathrm{kg}^{-1}\right. \\
\text { soil })\end{array}$ & $\begin{array}{c}\text { Available } \\
\text { Phosphorus } \\
\left(\mu g \mathbf{P ~ g}^{-1} \text { soil) }\right.\end{array}$ & $\begin{array}{c}\text { Organic } \\
\text { matter } \\
(\%)\end{array}$ \\
\hline Sita-Eliya & $5.99^{\mathrm{a}}$ & $230.5^{\mathrm{a}}$ & $2.7^{\mathrm{a}}$ & $30.8^{\mathrm{a}}$ & $138.4^{\mathrm{a}}$ & $5.8^{\mathrm{a}}$ \\
\hline Rahangala & $6.19^{\mathrm{a}}$ & $102.3^{\mathrm{b}}$ & $0.8^{\mathrm{b}}$ & $16.1^{\mathrm{a}}$ & $42.9^{\mathrm{b}}$ & $3.5^{\mathrm{a}}$ \\
\hline
\end{tabular}

Along each column, means with the same letter are not significantly different at $\mathrm{p}=0.05$.

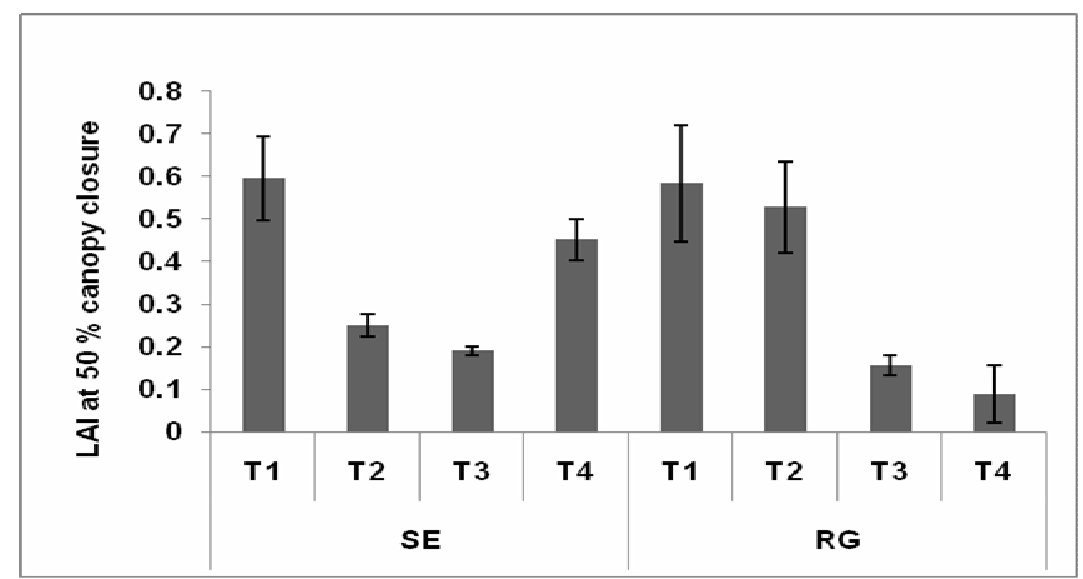

Fig. 2. Variation of LAI of potato at $50 \%$ canopy closure in $T_{1}-T_{4}$ at the two locations: SE-Sita-Eliya; RG-Rahangala. $T_{1}-$ Recommended nutrient management and crop protection (Control); $T_{2}-$ Recommended nutrient management and crop protection + Mulching at $8 \mathrm{t} \mathrm{ha}^{-1} ; \mathrm{T}_{3}-$ Recommended nutrient management + Mulching + IPM; $\mathrm{T}_{4}-$ Mulching + IPM $+25 \% \mathrm{~N}$ requirement supplied by organic manure. Error bars indicate standard errors of mean.

The treatment (site) effect was not significant $(\mathrm{p}=0.05)$ for total dry weight (TDW) at $50 \%$ canopy closure, but was highly significant $(\mathrm{p}=0.0003)$ for total biomass at final harvest (Table 3). When the TDW at the two sites was analyzed separately, TDW at the final harvest showed significant inter-treatment differences at both sites. In contrast, TDW at 50\% canopy closure did not show significant treatment variations at either of the two sites. At Sita-Eliya, $\mathrm{T}_{1}$ showed a significantly greater TDW at final harvest than the other three treatments, which did not differ significantly among themselves (Table 3). On the other hand, at Rahangala, both $T_{1}$ and $T_{2}$ showed significantly greater TDW at harvest than $T_{3}$ and $T_{4}$. 
Table 3. Variation of total crop dry weight and crop growth rate of potato at $50 \%$ canopy closure $(50 \% \mathrm{CC})$ and final harvest in $\mathbf{T}_{1}-\mathrm{T}_{4}$ at the two experimental sites

\begin{tabular}{|c|c|c|c|c|c|c|c|c|}
\hline \multirow[b]{3}{*}{$\begin{array}{l}\text { Treat- } \\
\text { ment }\end{array}$} & \multicolumn{4}{|c|}{ Total Dry Weight $\left(\right.$ g plant $\left.^{-1}\right)$} & \multicolumn{4}{|c|}{ Crop Growth Rate $\left(\mathrm{g} \mathrm{m}^{-2} \mathrm{~d}^{-1}\right)$} \\
\hline & \multicolumn{2}{|c|}{ Rahangala } & \multicolumn{2}{|c|}{ Sita-Eliya } & \multicolumn{2}{|c|}{ Rahangala } & \multicolumn{2}{|c|}{ Sita-Eliya } \\
\hline & $\begin{array}{c}50 \% \\
\text { CC }\end{array}$ & $\begin{array}{c}\text { Final } \\
\text { Harvest }\end{array}$ & $\begin{array}{c}\mathbf{5 0 \%} \\
\mathrm{CC}\end{array}$ & $\begin{array}{c}\text { Final } \\
\text { Harvest }\end{array}$ & $\begin{array}{c}\text { Up to } \\
50 \% \\
\text { CC }\end{array}$ & $\begin{array}{c}\text { Total } \\
\text { duration }\end{array}$ & $\begin{array}{c}\text { Up to } \\
50 \% \\
\text { CC }\end{array}$ & $\begin{array}{c}\text { Total } \\
\text { duration }\end{array}$ \\
\hline $\mathrm{T}_{1}$ & $60.9^{\mathrm{a}}$ & $118.6^{\mathrm{a}}$ & $68.1^{\mathrm{a}}$ & $119.1^{\mathrm{a}}$ & $5.89^{\mathrm{a}}$ & $9.76^{\mathrm{a}}$ & $5.89^{\mathrm{a}}$ & $7.15^{\mathrm{a}}$ \\
\hline $\mathrm{T}_{2}$ & $75.7^{\mathrm{a}}$ & $104.4^{\mathrm{a}}$ & $42.6^{\mathrm{a}}$ & $43.4^{\mathrm{b}}$ & $7.32^{\mathrm{a}}$ & $8.59^{\mathrm{a}}$ & $3.69^{\mathrm{a}}$ & $2.60^{\mathrm{b}}$ \\
\hline $\mathrm{T}_{3}$ & $41.2^{\mathrm{a}}$ & $48.7^{\mathrm{b}}$ & $61.8^{\mathrm{a}}$ & $70.4^{b}$ & $3.98^{\mathrm{a}}$ & $4.01^{\mathrm{b}}$ & $5.35^{\mathrm{a}}$ & $4.23^{b}$ \\
\hline $\mathrm{T}_{4}$ & $42.2^{\mathrm{a}}$ & $15.3^{b}$ & $47.7^{\mathrm{a}}$ & $55.6^{\mathrm{b}}$ & $4.07^{\mathrm{a}}$ & $1.26^{\mathrm{b}}$ & $4.13^{\mathrm{a}}$ & $3.34^{\mathrm{b}}$ \\
\hline
\end{tabular}

Along each column, means with the same letter are not significantly different at $\mathrm{p}=0.05$.

Within a given treatment, the variation of TDW at 50\% canopy closure between the two sites was broadly similar (Table 3 ) to that of LAI at $50 \%$ cc (Figure 2). While $\mathrm{T}_{1}$ did not differ between the two sites, there was a significant variation between the two sites for $T_{2}, T_{3}$ and $\mathrm{T}_{4}$. Rahangala had shown significantly greater TDW in $\mathrm{T}_{2}$ whereas Sita-Eliya had significantly greater TDW in $\mathrm{T}_{3}$ and $\mathrm{T}_{4}$. Despite, the substantial difference between the total crop durations of the two sites, their TDW at final harvest of the $T_{1}$ treatment were similar (Table 3). Between-site variations of TDW at final harvest in the rest of the treatments were similar to those of TDW and LAI at 50\% canopy closure.

Crop growth rates (CGR) of $\mathrm{T}_{1}$ up to $50 \%$ canopy closure were similar in both sites (Table 3). However, over the entire crop duration, CGR of $T_{1}$ was higher at Rahangala than at SitaEliya. Over both durations, CGR of $\mathrm{T}_{2}$ was higher at Rahangala. In contrast, the CGR of $\mathrm{T}_{3}$ was higher in Sita-Eliya over both durations. While the CGR of $\mathrm{T}_{4}$ up to $50 \%$ cc was similar between the two sites, over the entire crop duration, Sita-Eliya had a higher CGR. Higher incidence and severity of late blight (reported elsewhere in this paper) contributed to the lower CGRs of $\mathrm{T}_{3}$ and $\mathrm{T}_{4}$ at Rahangala.

\section{Yield parameters}

There was a highly-significant $(\mathrm{p}=0.0039)$ interaction between locations and treatments with respect to final tuber yield. When the yields of the two locations were analyzed separately, in Sita-Eliya, there was no significant variation in yield among the four treatments (Fig. 3). In contrast, at Rahangala, $T_{1}$ and $T_{2}$ had significantly greater yields than $T_{3}$ and $T_{4}$. The mean number of tubers per plant (MNTP) did not differ significantly at either of the two sites (Table 4). In contrast, the mean individual tuber weight (MITW) showed a highly significant $(\mathrm{p}<0.0001)$ inter-treatment variation at Rahangala, but not at Sita-Eliya (Table 4). At Rahangala, $T_{2}$ showed the highest MITW followed by $T_{1}$ while both $T_{3}$ and $T_{4}$ had significantly lower MITW than $\mathrm{T}_{2}$ and $\mathrm{T}_{1}$. Both yield components showed highly significant $(\mathrm{p}<0.0001)$ positive correlations with tuber yield with linear correlation coefficients $(r)$ of 0.761 and 0.841 for MNTP and MITW, respectively. However, there was no significant correlation between MNTP and MITW. The harvest index did not show significant variation among treatments or sites either at the mid-harvest stage (data not shown) or the final harvest stage (Table 4). The tuber yields of $\mathrm{T}_{1}$ and $\mathrm{T}_{2}$ did not differ significantly between the two sites. In contrast, yields of $\mathrm{T}_{3}$ and $\mathrm{T}_{4}$ at Sita-Eliya were significantly greater than those at 
Rahangala. The substantially greater incidence and severity of late blight (reported elsewhere in this paper) contributed to the lower yields of $\mathrm{T}_{3}$ and $\mathrm{T}_{4}$ at Rahangala.

Table 4. Variation of yield components and harvest index at final harvest of potato in $T_{1}-T_{4}$ at the two experimental sites

\begin{tabular}{ccccccc}
\hline \multirow{2}{*}{ Treatment } & \multicolumn{2}{c}{$\begin{array}{c}\text { Mean number of } \\
\text { tubers per plant }\end{array}$} & \multicolumn{2}{c}{$\begin{array}{c}\text { Mean individual tuber } \\
\text { fresh weight }(\mathbf{g})\end{array}$} & \multicolumn{2}{c}{ Harvest Index (\%) } \\
\cline { 2 - 6 } & SE & RG & SE & RG & SE & RG \\
\hline $\mathrm{T}_{1}$ & $5.7^{\mathrm{a}}$ & $6.3^{\mathrm{a}}$ & $71.71^{\mathrm{a}}$ & $67.93^{\mathrm{b}}$ & $88.70^{\mathrm{a}}$ & $85.93^{\mathrm{a}}$ \\
$\mathrm{T}_{2}$ & $5.7^{\mathrm{a}}$ & $5.8^{\mathrm{a}}$ & $78.76^{\mathrm{a}}$ & $77.15^{\mathrm{a}}$ & $83.53^{\mathrm{a}}$ & $88.09^{\mathrm{a}}$ \\
$\mathrm{T}_{3}$ & $4.5^{\mathrm{a}}$ & $4.1^{\mathrm{a}}$ & $82.77^{\mathrm{a}}$ & $46.68^{\mathrm{c}}$ & $88.05^{\mathrm{a}}$ & $86.98^{\mathrm{a}}$ \\
$\mathrm{T}_{4}$ & $5.0^{\mathrm{a}}$ & $4.8^{\mathrm{a}}$ & $70.14^{\mathrm{a}}$ & $42.22^{\mathrm{c}}$ & $83.82^{\mathrm{a}}$ & $76.20^{\mathrm{a}}$ \\
\hline
\end{tabular}

Along each column, means with the same letter are not significantly different at $\mathrm{p}=0.05$.

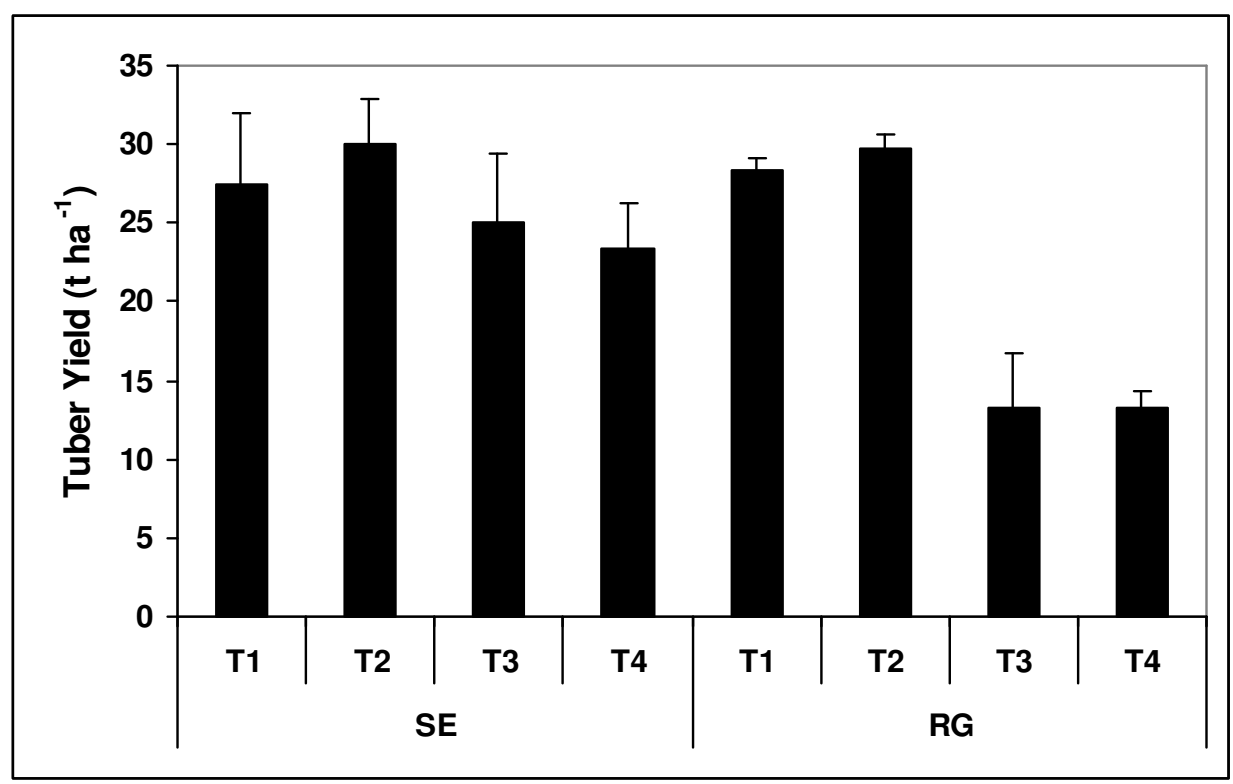

Fig. 3. Variation of tuber yield of potato in $T_{1}-T_{4}$ at the two experimental sites. Error bars indicate standard errors of mean.

\section{Relationships between yield and growth parameters}

When the data of both sites were pooled, tuber yield showed significant $(\mathrm{p}<0.05)$ positive correlations with LAI at $50 \%$ canopy closure $(\mathrm{r}=0.405$ at $\mathrm{p}=0.049)$ and TDW at final harvest $(r=0.499$ at $p=0.013)$. Furthermore, there was a highly significant positive correlation between the number of tubers per plant and TDW at final harvest $(r=0.533$ at $p$ $=0.0073$ ). On the other hand, the MITW showed a significant positive correlation with the LAI at $50 \%$ canopy closure $(r=0.398$ at $p=0.054)$. Among the growth parameters, there was a significant positive correlation between TDW and LAI at 50\% canopy closure $(\mathrm{r}=$ 0.409 at $\mathrm{p}=0.048$ ). Moreover, the TDW at final harvest showed significant positive 
correlations with LAI $(r=0.438$ at $\mathrm{p}=0.032)$ and TDW $(\mathrm{r}=0.720$ at $\mathrm{p}<0.0001)$ at $50 \%$ canopy closure.

\section{Disease incidence and severity}

Incidence of both late blight and bacterial wilt was either zero or very low at the initial and crop development stages (Fig. 4). However, the incidence of late blight increased substantially in the treatments with IPM (i.e. $\mathrm{T}_{3}$ and $\mathrm{T}_{4}$ ) at Rahangala from mid-season onwards. In contrast, with conventional non-IPM crop protection practices, which were mainly based on chemical applications (i.e. $\mathrm{T}_{1}$ and $\mathrm{T}_{2}$ ), late blight incidence was less than $8 \%$ at Rahangala even during the mid- and late season. In contrast to Rahangala, at SitaEliya, the IPM treatment was able to maintain late blight incidence below $30 \%$ even at midseason. Interestingly, at Sita-Eliya, the IPM treatments were as effective as the conventional non-IPM treatments in controlling the incidence of late blight. It is notable that the IPM package at Sita-Eliya was able to achieve a reduction in late blight incidence during late season when it was increasing in all other treatments. In comparison to late blight, the incidence of bacterial wilt was very low at both sites in both IPM and non-IPM treatments. However, similar to the corresponding observations on the incidence of late blight, the incidence of bacterial wilt was higher in crops under IPM at Rahangala. On the other hand, the opposite was true at Sita-Eliya with the crops under IPM showing a lower incidence of bacterial with in comparison to those without IPM.

The severity of late blight at Rahangala was substantially higher in the IPM treatment as compared to the non-IPM treatment (Fig. 4). At Sita-Eliya also the severity of late blight was higher in the IPM treatment from the initial stage up to the mid-season stage. However, the IPM treatment was able to reduce the severity of late blight during late season. Therefore, during late season, the severity of late blight was lower in the IPM treatment in comparison to the non-IPM treatment. In general, within a given crop protection practice, the incidence of both late blight and bacterial wilt and the severity of late blight were higher at Rahangala than at Sita-Eliya (Fig. 4). 

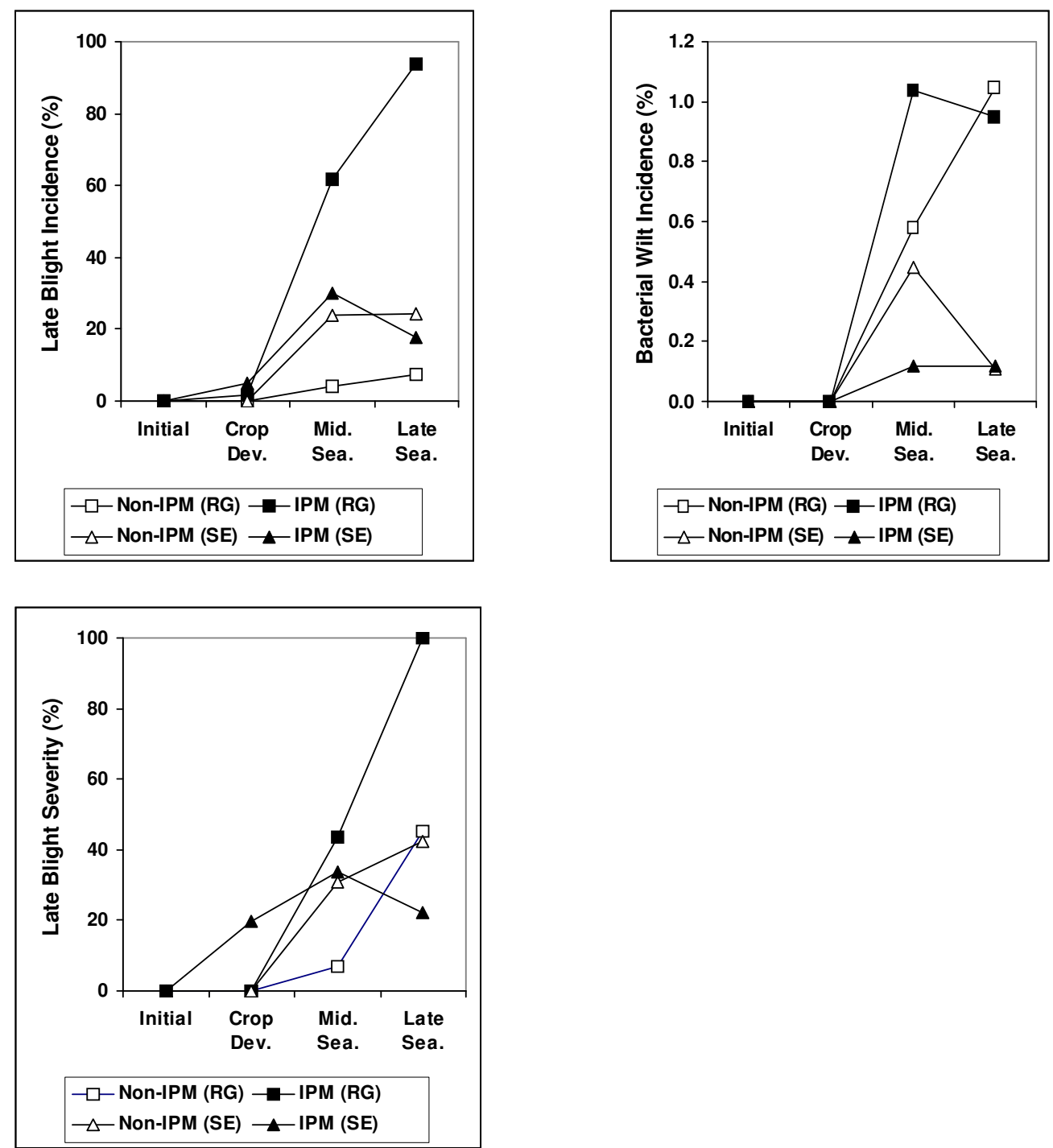

Figure 4. Variation of disease incidence of late blight and bacterial wilt and severity of late blight in potato grown in Rahangala (RG) and Sita-Eliya (SE) using conventional crop protection (Non-IPM) and Integrated Pest Management (IPM) at different stages of the crops. Crop Dev. - Crop development stage; Mid. Sea. - Mid-season; Late Sea. - Late season. 


\section{DISCUSSION}

\section{Response of potato crops to increasing temperature}

In the present study, potato crops were grown at two sites which had a mean seasonal temperature difference of $5.2{ }^{\circ} \mathrm{C}$ from the lower temperature site Sita-Eliya $\left(15.1{ }^{\circ} \mathrm{C}\right)$ to the relatively higher-temperature site Rahangala $\left(20.3{ }^{\circ} \mathrm{C}\right)$. Even though there was a seasonal rainfall difference of $502.2 \mathrm{~mm}$, supplementary irrigation ensured that the crops were grown without any limitation of water. Therefore, the observed variation of phenology, growth and yield of potato crops between the two sites primarily represented the response of these processes to temperature.

Within the treatment structure of the experiment, between-site variation of the control treatment (i.e. $\mathrm{T}_{1}$ ) can be taken as the specific response of potato to a temperature increase in the range from $15^{\circ}$ to $20^{\circ} \mathrm{C}$. Overall growth (Fig. 2 and Table 3) and yield (Fig. 3 and Table 4) performance of $T_{1}$ shows that both growth and yield of potato remained approximately constant across the above temperature range despite it representing a substantial increase in growing temperature. This indicates that the temperature range from $15^{\circ}$ to $20{ }^{\circ} \mathrm{C}$ is within the optimum range for potato, which is supported by several previous findings available in literature. For example, Timlin et al. (2006) found the highest total biomass at harvest at 20 ${ }^{\circ} \mathrm{C}$ in a controlled environmental chamber experiment which tested six growing constant temperatures ranging from $12^{\circ}$ to $32^{\circ} \mathrm{C}$. Sattelmacher et al. (1990) also found that the optimum temperature for root growth of potato was around $20{ }^{\circ} \mathrm{C}$. Fleisher et al. (2006) showed that leaf area per plant was maximum within the temperature range from $16.6^{\circ}$ to $22.1{ }^{\circ} \mathrm{C}$, again indicating the temperature optimum to be within this range. Furthermore, Fleisher et al. (2006) have shown that canopy photosynthetic rate of potato decreased at temperatures above $20{ }^{\circ} \mathrm{C}$. Hammes \& De Jager (1990) also showed a similar optimum temperature for net photosynthetic rate. However, results of the present experiment on the phenology and supporting growth measurements show that the stability of growth and yield within the tested temperature range have been achieved by the interplay of several processes which do respond significantly to the $5{ }^{\circ} \mathrm{C}$ temperature increase that was experienced by the potato crops of the present study.

The substantial temperature difference between the two sites caused a significant difference in phenological development of the crop at the higher-temperature site Rahangala completing its life cycle a month earlier by fulfilling the thermal time requirement. This agreed with the findings of Kooman et al. (1996) who showed that the length of the crop development phase from emergence to tuber initiation decreased with increasing temperature within the range from $14^{\circ}$ to $22^{\circ} \mathrm{C}$, which included the range of the present experiment (i.e. $15^{\circ}-20^{\circ} \mathrm{C}$ ). On the other hand, the higher temperature enabled the potato crops at Rahangala to achieve higher crop growth rates (CGRs) than at Sita-Eliya (Table 3). However, total dry weights at final harvest of the control treatments of both sites were similar because the lower CGR at Sita-Eliya was compensated by the longer crop duration. In contrast, despite the higher CGR, the higher temperature at Rahangala accelerated the phenological development of the crop and reduced the duration of the crop. The above-described influence of temperature on the interaction between CGR and phenological development is a major process in the physiology of yield determination of potato as tuber yield was significantly positively correlated with total dry weight at final harvest. It would be interesting to investigate the response of these processes at temperatures which are higher than $20^{\circ} \mathrm{C}$. 


\section{Effectiveness of the tested IPM package}

Results of the present study clearly showed that the tested IPM package was as effective as the non-IPM package in controlling late blight at Sita-Eliya, it was not effective at Rahangala. This was evidenced by the substantially greater incidence and severity of late blight in the IPM treatments as compared to non-IPM treatments at Rahangala (Fig. 4). Schumann and Arcy (2000) have shown that the optimum temperature for spore formation of Phytopthera infestans, the late blight-causing fungi, ranges from $18^{\circ}$ to $22^{\circ} \mathrm{C}$. Fig. 1 shows that the seasonal variation of temperature at Rahangala has been largely confined within the above range of temperatures, thus providing ideal conditions for development of late blight. In contrast, the seasonal variation of temperature at Sita-Eliya has largely been below $15^{\circ} \mathrm{C}$, which is sub-optimal for spore formation of the late blight pathogen. Hence, the IPM package tested in the present study has to be improved to withstand the stronger inoculum pool that would be present in the temperature regime prevailing at Rahangala. On the other hand, even the present IPM package can be used to reduce the application of chemical fungicides in potato cultivation without suffering a significant reduction in tuber yield in areas where the growing season temperatures are sub-optimal for disease development (i.e. < $\left.16-18^{\circ} \mathrm{C}\right)$.

\section{Effectiveness of mulching}

The $T_{2}$ treatment of the present study included mulching in combination with non-IPM-based crop protection. In contrast, in the $\mathrm{T}_{3}$ treatment mulching was combined with IPM. The results clearly showed that when practiced with non-IPM mulching was effective in promoting growth and yield formation at Rahangala so that LAI, total dry weights and yields of $\mathrm{T}_{2}$ were on par with those of $\mathrm{T}_{1}$ (Tables $3 \& 4$ and Figures $2 \& 3$ ). The greater response to mulching at Rahangala may be due to two possible reasons. As Rahangala had a substantially lower rainfall with a lower number of rain days in comparison to Sita-Eliya (Fig. 1), mulching probably contributed to improved soil moisture conservation in between irrigations. Secondly, the poorer soil conditions at Rahangala (Table 2) may have shown a greater response to the additional input of nutrients from the mulch. The growth performance of potato crops (in terms of LAI and TDW) under the $\mathrm{T}_{2}$ treatment at Sita-Eliya was inferior to the rest of the treatments at the same site (Fig. 2 and Table 3). However, in terms of yield and yield components (Fig. 3 and Table 4), performance of the $T_{2}$ at Sita-Eliya was on par with the rest of the treatments. It is possible that the lower temperatures at SitaEliya slowed down the decomposition and release of nutrients from the mulch so that its beneficial effects were on the processes that were taking place during second half of the life cycle of the potato crop (i.e. tuber initiation and tuber bulking).

\section{Effectiveness of modified nutrient management}

The $\mathrm{T}_{4}$ treatment of the present study tested the possibility of reducing the application of inorganic nitrogen fertilizer by applying $25 \%$ of the crop's $\mathrm{N}$ requirement through organic amendments. As the $\mathrm{T}_{4}$ treatment was combined with the IPM package, assessment of the effect of modified nutrient management has to be done by comparing the performance of $\mathrm{T}_{4}$ with that of $\mathrm{T}_{3}$ in which $100 \%$ inorganic $\mathrm{N}$ fertilization was combined with IPM. With the exception LAI at 50\% canopy closure at Sita-Eliya, there was no significant difference in growth and yield performance of potato crops under $\mathrm{T}_{4}$ and $\mathrm{T}_{3}$ treatments at both sites. This means that it is possible to reduce the use of inorganic fertilizer, specifically $\mathrm{N}$ in the present situation, and provide part of the nutrient requirement through organic amendments without suffering a significant yield reduction. Furthermore, it is notable that $\mathrm{T}_{4}$ showed a 
significantly greater LAI at 50\% canopy closure than the corresponding $\mathrm{T}_{3}$ at Sita-Eliya (Fig. 2 ), thus showing the superiority of the modified nutrient management over the conventional (i.e. $100 \%$ inorganic $\mathrm{N}$ ). Therefore, the option of increasing the fraction of the $\mathrm{N}$ requirement that could be replaced by organic amendments should be explored in future research.

\section{Physiology of yield determination of potato}

In addition to providing answers to the three principal research questions that were stated as specific objectives of the present study, its results provided insights in to the processes governing the physiology of yield determination of potato within the temperature range tested. The significant positive correlations between tuber yield and the two yield components (i.e. mean number of tubers per plant, MNTP, and mean individual tuber weight, MITW) show that potato yields can be increased by increasing either of the two yield components or both. The absence of a significant correlation between the two yield components indicates that they are determined independently and that increasing one yield component would not decrease the other. The significant positive correlations that the LAI at $50 \%$ canopy closure showed with tuber yield and MITW indicate that potato yields in the present study are primarily source-limited. The significant positive correlation between MNTP and yield may appear to indicate that yields of the present study are sink-limited as well. However, it is highly likely that this apparent sink limitation is a secondary effect as MNTP is positively correlated to TDW at final harvest, which in turn is positively correlated to LAI at $50 \%$ canopy closure.

\section{CONCLUSIONS}

The principal conclusions from the present study can be summarized as: (a) Potato yields did not decrease significantly when seasonal mean temperature in the up-country of Sri Lanka increased from $15^{\circ}$ to $20{ }^{\circ} \mathrm{C}$; (b) Faster phenological development and shorter life cycle duration of the crop at the higher temperature is compensated by higher crop growth rates, thus stabilizing the tuber yield across the tested temperature range; (c) The specific IPM package tested in the present study was effective in controlling the incidence and severity of late blight at temperatures which are sub-optimal for spore formation of the pathogen. However, the tested IPM package could not control the disease at temperatures which are optimum for sporulation; (d) It is possible to reduce the use of inorganic $\mathrm{N}$ fertilizer in potato cultivation in the up-country by replacing $25 \%$ of the crop's $\mathrm{N}$ requirement by organic amendments without a significant reduction in tuber yield; (e) The beneficial effects of mulching on growth and yield of potato are more pronounced at sites in the higher end of the temperature range tested in the present study (i.e. ca. $20{ }^{\circ} \mathrm{C}$ ). The lower rainfall and poorer soil conditions of these sites also contribute to the pronounced response to mulching; (f) Potato yields in the up-country of Sri Lanka are source-limited.

\section{ACKNOWLEDGEMENTS}

This project is being funded by the Higher Education for Twenty First Century (HETC) Quality and Innovation Grants Window 3 (QIG-3) project of the Ministry of Higher Education, Sri Lanka. Part of the meteorological data was provided by the Department of Agriculture, Sri Lanka. 


\section{REFERENCES}

Anonymous. (2010). Annual Report. Department of Census and Statistics, Colombo.

Anonymous (1990). Crop Recommendations Technoguide. Department of Agriculture. Sri Lanka.

Bodlaender, K.B.A. (1963). Influence of temperature, radiation and photoperiod on development and yield. pp. 199-210. In: J.D. Ivins and F.L. Milthorpe (Eds). The Growth of the Potato. Butterworths, U.K.

De Silva, G.G.R., Dassanayake, A.R. and Mapa, R.B. (2005). Soils of the mid country intermediate zone. pp. 121-125. In: Mapa, R. B., Dassanayake, A.R. and Nayakekorale, H. B. (Eds.). Soil of the Intermediate Zone of Sri Lanka. Morphology, Characterization and Classification. Special Publication No. 4. Soil Science Society of Sri Lanka.

Dissanayake, A.R. and Hettiarachchi, L.S.K. (1999). Soils of the up country wet zone. pp. 122-136. In: Mapa, R.B., Somasiri, S. and Nagarajah, S. (Eds.). Soils of the Wet Zone of Sri Lanka. Morphology, Characterization and Classification. Special Publication No.1. Soil Science Society of Sri Lanka.

Fleisher, D., Timlin, D.J. and Reddy, V.R. (2006). Temperature influence on potato leaf and branch distribution and on canopy photosynthetic rate. Agron. J. 98, $1442-1452$.

Gregory, L.E. (1965). Physiology of tuberization in plants. Encyclopaedia Plant Physiol. 15, $1328-1354$.

Hammes, P.S. and De Jager, J.A. (1990). Net photosynthetic rate of potato at high temperatures. Potato Res. 33, 515 - 520.

Hijmans, R.J. (2003). The effect of climate change on global potato production. American J. Potato Res. 80, 271 - 280.

IPCC, (2007). Climate Change 2007: Impacts, Adaptation and Vulnerability. In: Contribution of Working Group II to the Fourth Assessment Report of the Intergovernmental Panel on Climate Change. Parry, M.L., Canziani, O.F., Palutikof, J.P., van der Linden, P.J. \& Hanson, C.E. (Eds.), Cambridge University Press, Cambridge, UK.

IPCC, (2001). Climate Change, 2001. Impacts, Adaptation and Vulnerability: In: Contribution of Working Group II to the Third Assessment Report of the Intergovernmental Panel on Climate Change, Cambridge University Press.

Khan, M.A. and Khan, S.L. (2010). Potential markets of potato: Report of the Trade Development Authority of Pakistan.

Kooman, P.L., Haverkort, A.J., Kooman, P.L., Fahem, M. and Tegera, P. (1996). Effects of climate on different potato genotypes: II. Dry matter allocation and duration of the growth cycle. European J. Agron. 5, 207 - 217.

Nugaliyadda, M.M. (2011). Cultivation of Potato. Govi Janatha Bulletin. pp. 3-5. 
Pandey, S.K. (2008). Potato Research Priorities in Asia and the Pacific Region. [Online]. [Accessed on 28 $8^{\text {th }}$ August 2013]. Available at www.fao.org/docrep/010/io 200e/ IO 200E08.html.

Punyawardana, B.V.R. (2008). Evolution of climatic zoning in Sri Lanka. In: Agroclimatological Zones and Rainfall Pattern in Sri Lanka (in Sinhala medium). Published by Department of Agriculture, Sri Lanka. pp. 44-113 (ISBN 978-955-9282-19-8).

Robertson, G.P. and Vitousek, P.M. (2009). Nitrogen in Agriculture: Balancing the cost of an essential resource. Ann. Rev. Environ. Resour. 34, 97 - 125.

Sattelmacher, B., Marschner, H. and Kühne, P. (1990). Effects of the temperature of the rooting zone on the growth and development of roots of potato (Solanum tuberosum). Ann. Bot. $65,27-36$.

Schumann, G.L. and Arcy C.J.D. (2000). Late blight of potato and tomato. The Plant Health Instructor. DOI: 10.1094/PHI-I-2000-0724-01 .Updated 2005.

Suriyagoda, L.D.B., Ranil, R.H.G., Dissanayaka, D.M.S.B., Weerakkody, W.A.P (2012). The sustainability of intensive vegetable farming systems in Sri Lanka. ISHS: Chronica Horticulturae. 52, 14 - 17.

Timlin, D., Lutfor Rahman, S.M., Baker, J., Reddy, V.R., Fleisher, D. and Quebedeaux, B. (2006). Whole plant photosynthesis, development and carbon partitioning of potato as a function of temperature. Agron. J. 98, 1195 - 1203.

Van Ranset, E., Veloo, M., Dameyer, A. and Pauwels, M. (1999). Manual for the Soil Chemistry and Fertility Laboratory-Analytical Methods for Soils and Plants, Equipment, and Management of Consumables. NUGI 835, Ghent, Belgium (ISBN 90-76603 - 01-4).

Watawala, R.C., Liyanage, J.A. and Mallawatantri, A. (2009). Assessment of risk to water bodies due to residues of agricultural fungicide in intensive farming areas in the up country of Sri Lanka using an indicator model. Proceedings of the National Conference of Water, Food Security and Climate Change in Sri Lanka. Water Quality, Environment and Climate Change.9-11 June 2009, Colombo, 2, 69 - 75. (ISBN 978-92-9090-722-0).

Wheeler, R.M., Steffen, K.L., Tibbitts, T.W. and Palta, J.P. (1986). Utilization of potatoes for life support systems. II. The effects of temperature under 24-h and 12-h photoperiods. American Potato J. 63, 639 - 647.

Wijewardena, J.D.H. (1996). Fertilizer management under intensive cropping systems in Sri Lanka. Proceedings of the Regional Workshop on Fertilizer Concepts with Special Reference to Organic Fertilizers. 6-9 May 1996, Tagaytay, Philippines.

Wijewardena, J.D.H. (2001). Fertilizer and soil amendments use on potato in relation to soil fertility in rice based cropping systems of up-country of Sri Lanka. Annals of the Sri Lanka Department of Agriculture 3, 353 - 363.

Woff, S., Marani, A. and Rudich, J. (1990). Effects of temperature and photoperiod on assimilate partitioning in potato plants. Ann Bot. 66, 513 - 520. 